\title{
Anlam Oluşturma Yaklaşımına Dayalı Öğretimin Ortaokul 7. Sınıf Öğrencilerinin Enerji Dönüşümü Kavramına İlişkin
} Kavramsal Değişimlerine Etkisi

Merve Önol $^{1}$, Sabri Kocakülah ${ }^{2}$

\author{
${ }^{1}$ Fen Bilgisi Eğitimi Anabilim Dalı, Fen Bilimleri Enstitüsü, Balıkesir Üniversitesi, Balıkesir, Türkiye \\ ${ }^{2}$ Matematik ve Fen Bilimleri Eğitimi Bölümü, Necatibey Eğitim Fakültesi, Balıkesir Üniversitesi, Balıkesir, Türkiye
}

Sorumlu Yazar: Merve Önol, onolmerve@gmail.com

Makale Türü: Araştırma Makalesi

Bilgilendirme: $\mathrm{Bu}$ çalışma birinci yazarın ikinci yazarın danışmanlığında gerçekleştirdiği doktora tez çalışmasının bir bölümüdür.

Kaynak Gösterimi: Önol, M., \& Kocakülah, S. (2021). Anlam oluşturma yaklaşımına dayalı öğretimin ortaokul 7. sınıf öğrencilerinin enerji dönüşümü kavramına ilişkin kavramsal değişimlerine etkisi. Eğitimde Kuram ve Uygulama, 17(1), 20-38. doi: $10.17244 /$ eku. 903628

Etik Not: Araştırma ve yayın etiğine uyulmuştur. Bu çalışmada veriler 2020 yılı öncesi toplanmış olup, veri toplama sürecinde katılımcıların gönüllü katılımı gözetilmiştir.

The Effects of Teaching Based on the Meaning-Making Approach on 7th Grade Students' Conceptual Change Concerning the Idea of Energy Conversion

Merve Önol $^{1}$, Sabri Kocakülah ${ }^{2}$

${ }^{1}$ Department of Science Education, Graduate School of Science, Balikesir University, Balikesir, Turkey

${ }^{2}$ Department of Mathematics and Science Education, Necatibey Faculty of Education, Balikesir University, Balikesir, Turkey

Corresponding Author: Merve Önol, onolmerve@gmail.com

Article Type: Research Article

Acknowledgement: This study is a part of the first author's doctoral thesis completed under the guidance of second author.

To Cite This Article: Önol, M., \& Kocakülah, S. (2021). Anlam oluşturma yaklaşımına dayalı öğretimin ortaokul 7. sınıf öğrencilerinin enerji dönüşümü kavramına ilişkin kavramsal değişimlerine etkisi. Ĕ̆itimde Kuram ve Uygulama, 17(1), 20-38. doi: $10.17244 /$ eku. 903628

Ethical Note: Research and publication ethics were followed. In this study, the data were collected before 2020, and voluntary participation of study group was observed during the data collection period. 


\title{
Anlam Oluşturma Yaklaşımına Dayalı Öğretimin Ortaokul 7. Sınıf Öğrencilerinin Enerji Dönüşümü
}

\section{Kavramına İlişkin Kavramsal Değişimlerine Etkisi}

\author{
Merve Önol ${ }^{1}$, Sabri Kocakülah ${ }^{2}$ \\ ${ }^{1}$ Fen Bilgisi Eğitimi Anabilim Dall, Fen Bilimleri Enstitüsü, Balıkesir Üniversitesi, Balıkesir, Türkiye \\ ${ }^{2}$ Matematik ve Fen Bilimleri Eğitimi Bölümü, Necatibey Eğitim Fakültesi, Balıkesir Üniversitesi, Balıkesir, Türkiye
}

ORCID: https://orcid.org/0000-0001-7575-3435

ORCID: https://orcid.org/0000-0002-4119-8477

\begin{tabular}{|c|c|}
\hline Öz & Makale Bilgisi \\
\hline $\begin{array}{l}\text { Bu araştırmanın amacı anlam oluşturma yaklaşımının kullanıldığı öğretimin } 7 \text {. sınıf } \\
\text { öğrencilerinin enerji dönüşümü kavramı ile ilgili kavramsal değişimlerine etkisini } \\
\text { incelemektir. Araştırmada nitel araştırma yöntemlerinden iç içe geçmiş tek durum deseni } \\
\text { kullanılmıştı̈. Çalışma grubu olarak Türkiye'nin batısında bulunan bir ildeki ortaokulda } \\
\text { öğrenim gören } 33 \text { öğrenci seçilmiştir. Örneklem olarak seçilen okulda bulunan bir sınıf } \\
\text { deney, bir sınıf kontrol grubu olarak belirlenmiş ve gruplar rastgele belirlenmiştir. } \\
\text { Öğrencilerin tasarlanan öğretim sürecinde kavramsal değişimlerini incelemek amacıyla } \\
\text { öğretim öncesinde ve sonrasında kavramsal anlama testi ile yarı yapılandırılmış } \\
\text { görüşmeler kullanılmıştır. Çalışma bulgularına göre her iki grupta öğrencilerin öğretim } \\
\text { öncesi yanıtları çoğunlukla "Yanlış Kavramlarla Açıklama" kategorisine uygun } \\
\text { bulunmuştur. Bu bulgularda öğrencilerin kinetik enerjiyi sadece hareketle ilişkilendirdiği } \\
\text { ve enerji dönüşümü ile ilgili bilimsel bilgiye sahip olmadıkları görülmektedir. Öğretim } \\
\text { sonrası deney grubunda yanıtları "Geçerli Açılama" kategorisinde yer alan öğrenci } \\
\text { sayısında artış görülmüştür. Potansiyel ve kinetik enerji hakkında bilimsel bilgiyi edinerek } \\
\text { bu iki enerjinin birbirine dönüşümünden bahseden öğrenci sayısı deney grubunda daha } \\
\text { fazla bulunmuştur. Bu nedenle araştırmanın sonunda anlam oluşturma yaklaşımının enerji } \\
\text { dönüşümü kavramına ilişkin kavramsal değişimde ve akademik başarıyı artırmada etkili } \\
\text { olduğu sonucu ortaya çıkmıştır. }\end{array}$ & $\begin{array}{l}\text { Makale Geçmişi: } \\
\text { Geliş: } 26 \text { Mart } 2021 \\
\text { Düzeltme: } 29 \text { Mayıs } 2021 \\
\text { Kabul: } 30 \text { Mayıs } 2021 \\
\text { Makale Türü: Araştırma } \\
\text { Makalesi }\end{array}$ \\
\hline
\end{tabular}

Etik Not: Araştırma ve yayın etiğine uyulmuştur. Bu çalışmada veriler 2020 yılı öncesi toplanmış olup, veri toplama sürecinde katılımcıların gönüllü katılımı gözetilmiştir. 
The Effects of Teaching Based on the Meaning-Making Approach on 7th Grade Students' Conceptual

Change Concerning the Idea of Energy Conversion

Abstract
The aim of this study is to examine the change in the students' conceptual understanding
of the concept of energy conversion by means of teaching activities based on the meaning
making approach. In the current study, embedded single case design was preferred. The
sample of this research was composed of 33 students who were enrolled in two different
7 th grade classes of a middle school in a province in the west of Turkey. Students in one
class of the school was assigned randomly to the control group and experimental group.
Conceptual understanding test and semi-structured interviews were employed to
determine the development of concepts in the students at the end of the teaching process.
According to the findings of the study, the pre-teaching responses of the students in both
groups are mostly in the "Incorrect Concepts" category. Findings of the study also show
that students in both groups only associate kinetic energy with movement and do not have
scientific knowledge about energy conversion. It is striking that the number of students
who obtained scientific information about potential and kinetic energy and talked about
the transformation of these two energies after teaching, was higher than the students in the
control group. It is concluded that the meaning-making approach has been found to be
effective in creating the conceptual change.

Article Info

Keywords: Conceptual change, Energy conversion, Meaning making approach

Article History:

Received: 26 March 2021

Revised: 29 May 2021

Accepted: 30 May 2021

Article Type: Research Article 


\section{Extended Summary}

\section{Introduction}

Meaning-making approach is included in social constructivist learning theory due to the existence of interactive learning environments. The social constructivist theory argues that the use of methods and techniques based on group studies and interactive learning, which improves the zone of proximal development of the individual in the classroom environment, has a significant effect on students' meaning-making process. Meaning-making processes are affected by the social interactions between individuals or by the interaction of individuals with other cultural products in their environment. Students learn to make sense of what they have learned and defend their thought with the discussion between student-student or student-teacher in the classroom. To examine how learning takes place in the classroom environment, students' speaking and communication situations should be examined (Mortimer \& Scott, 2003). In this respect, to examine the meaning-making processes in science classes in terms of sociocultural perspective, the types of interaction between teachers and students should be focused on. According to the analytical framework created by Mortimer and Scott (2003), the focus dimension includes the components that the teacher should focus on during teaching whereas the approach dimension is related to the teachers' ability to reveal different ideas and explain the correct idea directly. Finally, the action dimension is related to the structure of teachers' interaction with students.

The research aims to examine the effects of meaning-making approach on the 7th-grade students' learning about the concepts of energy conversion. For this aim, the study has sought answers to the following questions:

1. What is the students' pre-teaching conceptual understanding of the concept of energy conversion?

2. What is the students' post-teaching conceptual understanding of the concept of energy conversion?

\section{Method}

This study followed a qualitative research design. It is a case study which involves an up-close, in-depth, and detailed examination of a particular case or cases, within a real-world context. Among the case study designs, embedded single case design, in which more than one analysis unit is used, was preferred. The sample of this research was composed of 33 students who were enrolled in two different $7^{\text {th }}$ grade classes of a middle school in a province in the west of Turkey.

The teaching plan was prepared and applied by the researchers according to the components of meaningmaking approach process developed by Mortimer and Scott (2003). In the teaching plan, the meaning-making approach was adapted with the "Generative Learning Model of Teaching", which is based on the conflict of ideas, one of the conceptual change strategies proposed by Cosgrove and Osborne (1985). Conceptual Understanding Test and semi-structured interviews, which were developed by researchers, are data collection tools of the research. In this study, two questions in the Conceptual Understanding Test with 11 open-ended questions have evaluated students' attainments and their learning about the concept of energy conversion, so we share only findings related to these questions.

\section{Findings}

The pre-test findings of the study show that the answers of both experimental and control group students before teaching did not contain full scientific information and that these answers were not suitable for the accepted "Sound Explanation" category. Before the teaching, the student answers in both groups were mostly in the "Incorrect Explanation" category. It has been observed that the students thought that energy was directly associated with the concept of "motion" and that the pendulum had no energy at the point where it was assumed to stop. After the teaching, more answers were found in the Sound Explanation category in the experimental group than the control group. It turned out that some students had not been able to correct their misconceptions and continued to use the same misconceptions in the control group.

\section{Results and Discussion}

The findings show that the social communication of the students among themselves, and with the first researcher, and their prior knowledge and misconceptions, which originate from their daily lives, have changed towards scientific concepts. It has been observed that after the teaching intervention, the answers given by the experimental group mostly contain scientific knowledge. According to these results, it can be inferred that the teaching design by the meaning-making approach used in science teaching is effective in improving students' conceptual understanding and increasing their academic success. In the study, in-group and inter-group discussion environments were created by the perception of "learning is a social process" of the meaning-making approach, and students had the opportunity to present their ideas and share these ideas with other friends. In this way, it seems the discussions have affected the students' ideas, and had an effect on understanding the concept and on starting the conceptual change process by experiencing cognitive conflict. The teaching plans will be prepared using a similar teaching approach and the model employed in this study can be applied to students in different provinces at the same grade level. It is suggested that 
such applications will contribute to the external validity of this research. Furthermore, lesson plans based on the teaching approach and the model adopted in the current study can be applied to students at different grade levels and subjects. Thus, it can be confirmed whether the teaching approach of this study creates similar learning outcomes in different subjects. 


\section{Giriş}

Yapılandırmacılık kuramına göre öğrenme, anlam oluşturma olarak kabul edilmektedir ve bireyler, bilgiyi çevrelerinden doğrudan edinmek yerine etkin olarak kendi anlamlarını oluşturmalıdır (Phillips, 2000). Son yıllarda yapılan çalışmalar anlamlı öğrenmeyi merkezine alan yapılandırmacı eğitim anlayışı ile yeni öğretim modellerinin üretilmesine dayanmaktadır. Öğrenme, öğrenenin zihninde şekillenen kişisel anlamaların sosyo-kültürel bağlamda kişiler arası etkileşimlerle oluşturulmasına dayalı anlam oluşturma sürecidir (Mortimer \& Scott, 2003). Öğrenme bu açıdan ele alındığında "Anlam Oluşturma Yaklaşımı"nın yapılandırmacı eğitim yaklaşımlarına uygun bir yaklaşım olduğu ve etkileşimli öğrenme ortamlarının varlığı nedeni ile sosyal yapılandırmacı öğrenme kuramı içerisinde yer aldığı görülmektedir (Scott, Mortimer, \& Aguiar, 2006).

Bireyler arasındaki sosyal etkileşimlerin ya da bireylerin çevresindeki diğer bilgi kaynaklarından ulaşabilecekleri kültürel ürünlerle olan ilişkinin anlam oluşturma süreçleri üzerinde etkisi olduğu düşünülmektedir (Leach \& Scott, 2003). Bireyler bu süreçte çevreyle etkileşim kurarken ihtiyaçları olan bilgiyi edinmekte ve anlamlandırmaktadır. Bu süreçte, bireylerin edindikleri bilgiyi yaratması ve yapılandırması ile kendi öğrenme deneyimlerinin gerçekleşmesi sağlanır (Selvi, 2012). Bir başka deyişle, bireyin çevresiyle etkileşimi sırasında dışarıdan etki eden uyarıcıların algılanması ve bunların mevcut bilgilerle karşılaştırılması, yeni bilgilerin oluşturulması, yeni bilgilerin belleğe yerleştirilmesi ile zihinsel çıktıların mantıksal olarak değerlendirilmesi, biliş kapsamına giren zihinsel süreçlerle ilgili etkinliklerdir (Öztürk Ova, 2011).

Bireyin var olan bilgiye doğrudan ulaşmasından çok kendi zihninde kavramların anlamını yapılandırmasını ve bunu da sosyal ortamlarda dil aracılığıyla gerçekleştirmesini savunan sosyal yapılandırmacılık kuramına göre bilginin yapılandırılmasında sosyal ortam önemlidir (Moll \& Whitmore, 1993; Schunk, 2011). Bu kuramın öncüsü Vygotsky'e göre kişinin konuşarak öğrenmesi bilişsel gelişim açısından oldukça önemlidir (Derry, 1999; Terwel, 1999). Fen eğitimi ile ilgili yapılan çalışmaların odak noktası, Vygotsky'nin sosyokültürel kuramı çerçevesinde etkileşimli öğrenme ve bireylerin yakınsal gelişim alanındaki değişimler olmaya başlamıştır (Alyar \& Doymuş, 2015; Gilbert, Bulte, \& Pilot, 2011; Eun, 2017; Kıryak \& Çepni, 2015; Murphy, Scantlebury, \& Milne, 2015; Siyepu, 2013). Bu çalışmaların ortak amacı, sosyal ortamın ve etkileşim halinde gerçekleştirilen öğretimlerin öğrencilerin kavramları yapılandırmasında ve anlamlandırmasındaki etkisini ve gerekliliğini ortaya koymaktır. Sosyal yapılandırmacı ögrenme kuramının öğrencilerin birbirleri ile fikir alışverişinde bulunduğunda birbirlerinin yakınsal gelişim alanlarındaki gelişime katkı sağladığı ve öğrenmenin sosyal ortamlarda daha etkili gerçekleștiği görüşü bu araştırmanın temelini oluşturmaktadır. Çünkü sosyal yapılandırmacilığa göre öğrenme süreci etkileşimli ortamda anlam oluşturma olarak ele alınmaktadır (Oldfather, West, White, \& Wilmarth, 1999).

\section{Sosyal yapılandırmacılık ve Anlam Oluşturma Yaklaşımı İlişkisi}

Vygotsky'e göre anlam oluşturma, sosyal ortamlarda etkileşim sonucu meydana gelen içsel bir algıdır ve bilişin gelişiminde temel rolü bulunmaktadır (Bostan Sarığlan, 2013). Farklı bir deyişle anlam oluşturma, bireyler arasındaki sosyal etkileşimlerden veya bireylerin kitaplarda ya da diğer kaynaklarda kendilerine sunulan kültürel ürünlerle etkileşimi sonucu gerçekleşmektedir (Leach \& Scott, 2003). Vygotsky, öğrenme sırasında bilgiyi içselleştirirken ve anlam oluştururken bilimsel dili doğru kullanmanın önemini vurgulamıştır (Oldfather vd.,1999; Mortimer \& Scott, 2003). Vygotsky'nin çalışmaları özellikle çocukların anlam oluşturma süreçlerinin geliştirilmesinin sosyal ve kültürel bağlamlarda birçok yönü kapsadığını göstermektedir (Rieber, 1998). Çalışmalarının odak noktası özellikle "konuşma-düşünme becerileri” ve bu boyutta "anlam oluşturmaları" üzerine olmuştur (Mahn, 2012).

Sosyal yapılandırmacı kuram, bireyin yakınsak gelişim alanını geliştirici grup çalışmalarının ve etkileşimli öğrenmeyi temel alan yöntem ve tekniklerin sınıf ortamında kullanılmasının öğrencilerin anlam oluşturması üzerinde önemli bir etkisi olduğunu savunmaktadır (Baykal, 2014). Vygotsky, öğrencilerin öğrenme sürecinde edindikleri bilimsel bilgileri anlamlandırabilmek için özellikle sosyal ortamdaki konuşma süreçlerine aktif olarak katılmalarının gerekliliğine vurgu yapmaktadır (Kaya \& Kılıç, 2010). Bahsi geçen aktif katılımlar sosyal ortamlarda yazma, düşünme veya konuşma vasıtasıyla oluşturulan bir etkinlik olan tartışma ile sağlanabilir (Driver, Osborne, \& Newton, 2000). Sınıf içerisinde öğrenci - öğrenci ya da öğrenci - öğretmen arasında oluşturulan tartışma ortamı ile öğrenciler öğrendiklerini anlamlandırmayı, konuyla ilgili düşünce ve öğrenmelerini ifade etmeyi ve farklı düşüncelere karşı kendi düşüncelerini bilimsel ve mantıklı dayanaklarla savunmayı öğrenirler (Üstünkaya \& Gencer, 2012).

Sınıf ortamında öğrenmenin nasıl gerçekleştiği incelenmek istendiğinde irdelenmesi gereken öğrencilerin konuşma ve iletişim durumları olmalıdır (Furberg \& Arnseth, 2009; Mortimer \& Scott, 2003; Wertsch, 1991). Scott ve Mortimer (2003), fen sınıflarında anlam oluşturma süreçlerini sosyokültürel bakış açısıyla incelemek için geliştirdikleri yapıda, sınıf ortamında öğretmen ve öğrenciler arasındaki etkileşim türlerine odaklanmış ve bu etkileşim türlerinin anlam oluşturma sürecine nasıl etki ettiğini açıklamışlardır. Bu yapıda öğrenmenin içselleştirme sürecinde sosyal ortamın ve dilin öneminden bahseden Vygotsky'nin ve anlam oluşturmada diyaloğa dayalı bir süreçten bahseden Bakhtin'in görüşleri benimsenerek bilim öğrenmenin temelinde bilimsel dili öğrenme olduğu savunulmaktadır (Baykal, 2014). Mortimer ve Scott (2003)'un fen sınıflarında öğretim için oluşturmuş olduğu anlam 
oluşturma süreci için analiz çerçevesine göre bileşenler Tablo 1'de verilmiştir. Bu analiz çerçevesine göre odak boyutu öğretmenin öğretim sırasında odaklanması gereken bileşenlerle, yaklaşım boyutu öğretmenlerin farklı fikirleri ortaya koyması ve doğru olan fikri doğrudan açıklayabilmesiyle ve uygulama boyutu öğretmenin öğrencilerle etkileşiminin yapısıyla ilişkilidir.

Tablo 1. Mortimer ve Scott (2003)'1n Anlam oluşturma analiz çerçevesi

\begin{tabular}{cll}
\hline & \multicolumn{1}{c}{ Analiz Çerçevesi } & \multicolumn{1}{c}{ İçerik } \\
\hline Odak (Focus) & $>$ Öğretimin Amaçlart & (Content) \\
& (Teaching Purposes) & \\
Yaklaşım (Approach) & $>$ İletişimsel Yaklaşım & $>$ Ögretmen Müdahalesi \\
Uygulama (Action) & $>$ Communicative Approach) & (Teacher Interventions) \\
\hline
\end{tabular}

Leach ve Scott (2002), fen öğretimi üzerine yaptıkları çalışmalarında öğretim sırasında öğrenenlerin anlam oluşturmalarıyla ilgili olarak "öğrenme ihtiyacı (learning demand)" kavramını geliştirmişlerdir. Onlara göre öğrenme ihtiyacı, okulda kullanılan bilimin sosyal dili ile öğrencinin sınıfa getirdiği sosyal dilin arasındaki farklılıkları görmeyi ve değerlendirmeyi sağlamaktadır. Öğrenciler sınıf ortamına bilimsel bilgiyle tam olarak ilgisi olmayan, çevrelerindeki olay ve durumlara olan meraklarının etkisiyle bulundukları sosyal ortamlar sayesinde geliştirdikleri bilgilerle gelirler (Çinici, 2011; Driver, Leach, Scott, \& Wood-Robinson, 1994; Dale Tunnicliffe \& Gkouskou, 2020). Sınıfta kullanılan bilimsel dil ve ögrencilerin sınıfa getirdikleri günlük sosyal dil arasındaki farktan bahsedildiğinde ise karşımıza öğrencilerin sahip oldukları "kavram yanılgısı (misconception)" veya "alternatif kavrama (alternative conception)" kavramları çıkmaktadır. Öğrencilerin sahip olduğu bu kavram yanılgıları onların bilimsel bilgiyi doğru olarak öğrenmesini olumsuz yönde etkilemektedir (Şahin \& Çepni, 2012).

Öğrencilerin zihninde bulunan ilgili kavrama ait önbilgiler, yeni bilgileri öğrenmesinde kritik bir rol oynamaktadır (Alexander \& Dochy, 1995). Öğrencilerin özellikle günlük yaşamda farklı anlamlarda da kullanılan enerji ve enerji dönüşümü kavramları ile ilgili yanılgılar içeren ön bilgilerle sınıf ortamına gelmesi bu kavramın öğretilmesini zorlaştırmaktadır (Yeh, Huang, \& Yu, 2017). Bunun önüne geçebilmek için de öğrencilerin öğretim öncesi ön bilgilerinde bulunan kavram yanılgılarının tespit edilmesi ve giderilmesi önerilmektedir (Yağbasan \& Gülçiçek, 2003). Alanyazın incelendiğinde kavram yanılgılarını giderme ve kavramların daha etkin öğretimini sağlama üzerine önerilen yaklaşımları içeren çalışmalarda 5E öğretim modeli (Bıyıklı \& Yağc1, 2015; Phaikhumnam \& Yuenyong, 2018; Feyzioğlu - Yıldız \& Ergin, 2012), ikili yerleşik öğrenme (İpek - Akbulut, Şahin, \& Çepni, 2013), probleme dayalı öğrenme (Rakkapao, Pengpan, Srikeaw, \& Prasitpong, 2013; Şencan, 2013) ve işbirlikli öğrenmeyi (Kıncal, Ergül \& Timur, 2007) içeren çalışmalar ile karşılaşılmaktadır. Yapılan kaynak taraması sonucunda anlam oluşturma yaklaşımı ile enerji dönüşümü kavramının öğretimini gerçekleştirerek, öğrencilerin kavram yanılgılarının tespit edildiği ve kavramsal anlamalarının incelendiği bir çalışma ile karşılaşılmamıştır.

\section{Araştırmanın Amacı}

$\mathrm{Bu}$ araştırmanın amacı, anlam oluşturma yaklaşımının kullanıldığı ortaokul 7. sınıf öğrencilerinin enerji dönüşümü kavramına ilişkin kavramsal değişimlerine etkisini incelemektir. Bu amaç doğrultusunda araştırmada aşağıdaki araştırma problemlerine yanıt aranmıştır:

1. Öğrencilerin enerji dönüşümü kavramına ilişkin öğretim öncesi kavramsal anlamaları hangi düzeydedir?

2. Öğrencilerin enerji dönüşümü kavramına ilişkin öğretim sonrası kavramsal anlamaları hangi düzeydedir?

Yöntem

\section{Araştırmanın Modeli}

Araştırma, veri toplama ve verilerin analizi süreci bakımından nitel bir çalışmadır. Bu araştırma bir ya da birkaç durumu derinliğine araştırıp bütüncül bir yaklaşım ile durumun nasıl etkilendiğini açıklamaya çalışan durum çalışmasıdır (Yıldırım ve Şimşek, 2011). Durum çalışması desenlerinden ise içerisinde birden fazla analiz birimi bulunan durumların incelenmesi dahilinde kullanılan iç içe geçmiş tek durum deseni tercih edilmiştir (Aytaçlı, 2012; Yıldırım ve Şimşek, 2011). Araştırmanın deseni ve yapılan işlemler Tablo 2'de gösterilmiştir. 
Tablo 2. Araștırmanın deseni

\begin{tabular}{|c|c|c|c|}
\hline Grup & Ön Ölçümler & İşlemler & Son Ölçümler \\
\hline 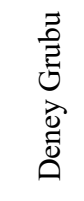 & $\begin{array}{l}\text { - Kavramsal Anlama Testi } \\
\text { - Kavramsal Anlama Testi soruları ile } \\
\text { yarı yapılandırılmış görüşme }\end{array}$ & $\begin{array}{l}\text { 7. sınıf öğretim programı kapsamında } \\
\text { Anlam Oluşturma Yaklaşımına göre } \\
\text { planlanan öğretim }\end{array}$ & $\begin{array}{l}\text { - Kavramsal Anlama Testi } \\
\text { - Kavramsal Anlama Testi soruları ile yarı } \\
\text { yapılandırılmış görüşme }\end{array}$ \\
\hline 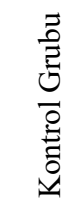 & $\begin{array}{l}\text { - Kavramsal Anlama Testi soruları ile } \\
\text { yarı yapılandırılmış görüşme }\end{array}$ & $\begin{array}{l}\text { 7. sınıf öğretim programına göre ders } \\
\text { öğretmeni tarafından planlanan öğretim }\end{array}$ & $\begin{array}{l}\text { - Kavramsal Anlama Testi soruları ile yarı } \\
\text { yapılandırılmış görüşme }\end{array}$ \\
\hline
\end{tabular}

\section{Araştırmanın Çalışma Grubu}

Araştırmanın çalışma grubunu Türkiye'nin batısında bulunan bir ildeki ortaokulun iki 7. sınıfında öğrenim görmekte olan 33 öğrenciden oluşturmaktadır. Araştırmada seçilen okulun bir sınıfı deney, bir sınıfı kontrol grubu olarak belirlenmiştir. Deney grubunda 15, kontrol grubunda 18 öğrenci bulunmaktadır. Sinıflar rastgele deney ve kontrol grubu olarak belirlenmiştir.

\section{Veri Toplama Araçları}

Araştırmanın verileri araştırmacı tarafından 2016 - 2017 eğitim öğretim yılında toplanmıştır. Araştırma sürecinde araştırmacılar tarafindan geliştirilen ve ortaokul 7. sınıf Fen Bilimleri dersindeki Kuvvet ve Hareket ünitesinde yer alan kavramlar ile ilgili 11 adet açık uçlu sorudan oluşan Kavramsal Anlama Testi ön test ve son test olarak uygulanmıştır. Öğrencilerle kavramsal anlama testi uygulamaları öncesinde ve sonrasında yarı yapılandırılmış görüşmeler yapılarak öğrencilerin yanıtlarının çok yönlü incelenmesi amaçlanmıştır. $\mathrm{Bu}$ araştırmada öğrencilerin öğretim öncesi ve sonrası sadece enerji dönüşümü kavramına ilişkin kavramsal anlamaları ve öğretim süreci sonunda kavramsal gelişimleri incelenmiştir; dolayısıyla bu araştırma kapsamında sadece iki soruya verilen yanıtlar incelenmiştir. Kavramsal anlama testinde yer alan ve bu araştırmada kullanılan sorular öğrencilerin enerji dönüşümü ile ilgili kazanımlarını ve öğrenmelerini değerlendirmeyi amaçlayan sorulardandır. Şekil 1'de görülen bu sorular öğrencilerin "enerji” ve "enerji dönüşümü” kavramlarıyla ilgili öğrenmelerini ve bu kavramla ilgili bilimsel bilgiyi edinme durumlarını değerlendirmektedir.

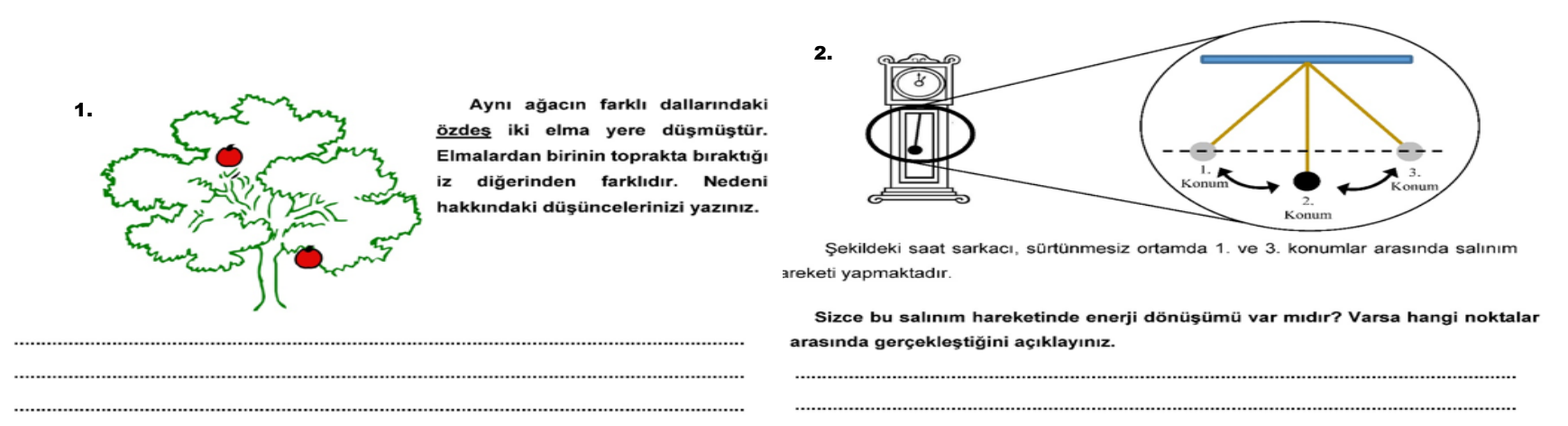

Şekil 1. Enerji dönüşümü kavramı ile ilgili 1. ve 2. Soru

Araştırmada öğrencilerle kavramsal anlama testi uygulamaları sonrasında yarı yapılandırılmış görüşmeler yapılarak öğrencilerin yanıtlarının çok yönlü olarak incelenmesi amaçlanmıştır. Enerji dönüşümünün tanımı, enerji dönüşümünün nasıl gerçekleştiği ile ilgili öğrencilerin görüşmelerini belirleyebilmek için kavramsal anlama testi soruları ile görüşme formu hazırlanmıştır. Görüşme formunda kavramsal anlama testi ile aynı sorular kullanılmıştır. Böylelikle öğrencilerin kavramsal anlama testinde olduğu gibi açık uçlu sorulara verdikleri yanıtlar nitelik, bu yanıtların açıklamaları ise anlaşılma ve fikirlerini detaylandırma bakımından incelenerek görüşme verileri kavramsal anlama testinden elde edilen yanıtları desteklemek için kullanılmış, veri çeşitlemesinin yapılması amaçlanmıştır. Öğrencilerin tamamı ile kavramsal anlama testine ait sorular kullanılarak ortalama 20-35 dakika sürede yarı yapılandırılmış görüşmeler yapılmıştır. 


\section{Verilerin Analizi}

Kavramsal anlama testinde yer alan enerji dönüşümü kavramı ile ilgili sorular araştırmacılar tarafından hazırlanan puanlama anahtarı (rubrik) kullanılarak değerlendirilmiş ve kategorize edilmiştir. Değerlendirme için rubrikteki yanıt kategorileri oluşturulurken Abraham, Grzybowski, Renner ve Marek (1992) tarafindan kullanılan kategorileme tekniğinden esinlenilmiştir. Araştırmada kullanılan yanıt kategorileri ve kategorilere ait puanlar şöyledir:

- Geçerli Açılama: Doğru yanıt ve tam açıklama yapar. (3 puan)

- Kısmi Açıklama: Doğru yanıt fakat açıklama tam değildir. (2 puan)

- Yanlış Kavramlarla Açıklama: Bilimsel olarak kabul edilmeyen yanıt ve/veya açıklama yapılır. (1 puan)

- Hiç Açıklamama/Cevap Yok: Hiçbir açıklama yapılmadan boş bırakılmış yanıt bölümü. (0 puan)

Analiz sırasında öncelikle her bir soruya ilişkin tam doğru yanıt belirlenmiş ve bu tam yanıtlar fen bilgisi eğitimi alanında uzman bir kişi tarafından kontrol edilmiştir. Ardından öğrencilerin yanıtları tek tek incelenmiş ve yukarıdaki kategorilerden uygun olanına her bir soru için kaydedilmiştir. Böylelikle her soru için yanıtların frekans tablosu oluşturulmuştur.

Ön görüşme ve son görüşmeden elde edilen veriler yanıtların içeriğine bakılarak betimsel analiz yapılmıştır. Analiz sonucunda ortaya çıkan veriler, içeriğine göre kavramsal anlama testinin verileriyle uygun düşen kategori altında değerlendirilerek birlikte kullanılmıştır.

\section{Öğretim Süreci}

Deney grubuna ait öğretim planı, araştırmacılar tarafından Mortimer ve Scott (2003)'un geliştirdiği anlam oluşturma sürecinin bileşenlerine göre araştırmacılar tarafından tasarlanmış ve uygulanmıştır. Araştırmada kullanılan öğretim planı Cosgrove ve Osborne (1985) tarafından önerilen ve kavramsal değişim stratejilerinden fikirlerin çatışmasına dayalı "Öğretimin Üretken Öğrenme Modeli (Generative Learning Model of Teaching)" baz alınarak uygulanmıştır. Bu amaçla öğretim planlanırken anlam oluşturma sürecine ait bileşenler Öğretimin Üretken Öğrenme Modelinin dört basamağı olan başlangıç, odaklanma, cesaretlendirme (meydan okuma) ve uygulama basamakları içerisine araştırmacılar tarafından yerleştirilmiştir. Bu teknikte öğrencilerin ön bilgileri ortaya çıkartılarak derse motive edilmeye çalışılmakta ve öğretmenin yönelttiği sorularla öğrencilerin kendi görüşlerini sınamaları sağlanmaktadır (Kural \& Kocakülah, 2014).

Deney ve kontrol grubunda öğretim süreci birinci araştırmacı tarafından gerçekleştirilmiş ve yedi hafta (14 ders saati) sürmüştür. Her iki grupta enerji dönüşümü kavramının öğretimi üç ders saatinde gerçekleştirilmiştir. Şekil 2'de deney grubunda tasarlanan bir dersin analiz çerçevesi görülmektedir.

\begin{tabular}{|c|c|}
\hline \multicolumn{2}{|c|}{$\begin{array}{c}\text { Ders I'in Bașlangıı̣̂Așaması Anlam Olușturma } \\
\text { Analiz Çerçevesi }\end{array}$} \\
\hline Amaç & $\begin{array}{l}\text { Problemi açma: Enerji dönüșümü̈ hakkındaki } \\
\text { önbilgilerin ortaya çıkmasını sağlamak. }\end{array}$ \\
\hline İçerik & Günlük-Bilimsel \\
\hline Yaklașım & Etkileșimli/Diyalog \\
\hline Konușma Kalıbı & B-C-G-C-G \\
\hline Müdahale & Fikirleri seçme \\
\hline
\end{tabular}

\begin{tabular}{|c|c|}
\hline \multicolumn{2}{|c|}{$\begin{array}{l}\text { Ders I'in Odaklanma Așaması Anlam Olușturma } \\
\text { Analiz Çerçevesi }\end{array}$} \\
\hline Amaç & $\begin{array}{l}\text { Öğrencilerin görüșlerini keșfetme ve } \\
\text { derinlemesine inceleme: :Enerji dönüșümü kavramı } \\
\text { ile ilgili bilgilerini detaylı incelemek, kavram } \\
\text { hakkındaki yanlıș öğrenmelerini keșfetmek }\end{array}$ \\
\hline İçerik & Günlük-Bilimsel-Deneysel \\
\hline Yaklașım & Etkileșimli/Diyalog - Etkileșimli/Otoriter \\
\hline Konușma Kalıbı & $\begin{array}{l}\text { Araștırmacı-Öğrenci B-C-G } \\
\text { Öğrenci-Öğrenci B-C-G-D }\end{array}$ \\
\hline Müdahale & $\begin{array}{l}\text { Fikirleri paylașma } \\
\text { Öğrencilerin anlamalarını kontrol etme }\end{array}$ \\
\hline
\end{tabular}

\begin{tabular}{|c|c|}
\hline \multicolumn{2}{|c|}{$\begin{array}{c}\text { Ders I'in Cesaretlendirme Așaması Anlam } \\
\text { Olușturma Analiz Çerçevesi }\end{array}$} \\
\hline Amaç & $\begin{array}{l}\text { Bilimsel görüșü tanıtma ve geliștirme: : Enerji } \\
\text { dönüșümü kavramını bilimsel olarak açılamak } \\
\text { Öğrencilerin bilimsel fikirlerle çalıșmalarına } \\
\text { rehberlik etme ve içselleștirmelerini sağlama: } \\
\text { Enerji dönüșümü kavramın bireysel, grup içerisinde } \\
\text { tartıșılmasını sağlamak }\end{array}$ \\
\hline İçerik & Deneysel-Kuramsal, Tanımlama-Açıklama \\
\hline Yaklașım & $\begin{array}{l}\text { Etkileșimli olmayan/Diyalog } \\
\text { Etkileșimli olmayan/Otoriter }\end{array}$ \\
\hline Konușma Kalıbı & B-C-G-D \\
\hline Müdahale & $\begin{array}{l}\text { Fikirleri șekillendirme } \\
\text { Anahtar fikirleri belirtme }\end{array}$ \\
\hline
\end{tabular}

\begin{tabular}{|c|c|}
\hline \multicolumn{2}{|c|}{$\begin{array}{c}\text { Ders I'in Uygulama Așaması Anlam Olușturma } \\
\text { Analiz Çerçevesi }\end{array}$} \\
\hline Amaç & $\begin{array}{l}\text { Öğrencilerin bilimsel görüșü uygulama ve } \\
\text { kullanımını genișletmede rehberlik etme, sorumluluk } \\
\text { verme: : Enerji dönüșümünü yorumlama ve enerji } \\
\text { dönüșümü gerçekleșen durumları ayırt etmeyi sağlamak } \\
\text { Bilimsel hikâyenin gelișimini destekleme: Enerji } \\
\text { dönüșümüne günlük yașantısından örnekler verecek } \\
\text { düzeye getirmek }\end{array}$ \\
\hline İçerik & Tanımlama-Açıklama-Genelleme \\
\hline Yaklașım & Etkileșimli/Diyalog \\
\hline Konușma Kalıbı & B-C-G-D \\
\hline Müdahale & $\begin{array}{l}\text { Öğrencilerin anlamalarını kontrol etme } \\
\text { Anlamaları yeniden gözden geçirme }\end{array}$ \\
\hline
\end{tabular}

Şekil 2. Ders 1'in analiz çerçevesi

Şekil 2'de görüldüğü gibi bir ders başlangıç, odaklanma, cesaretlendirme ve uygulama olmak üzere dört ana bölüme ayrılmış ve her bölüm anlam oluşturma yaklaşımına ait analiz çerçevesinin bileşenleri olan amaç, içerik, yaklaşım, konuşma kalıbı ve müdahale boyutlarında planlanmıştır. Böylelikle her aşamanın amacına uygun biçimde iletişimsel yaklaşım belirlenerek öğretim planlanmış ve bir döngü içinde derslerdeki iletişim sistematik hale getirilmiştir. Öğretimin ilk bölümü olan başlangıç aşaması öğrencilerin öğretim öncesi görüşlerini keşfetmeye yöneliktir. İkinci bölüm olan odaklanma aşamasında öğrencilerin görüşlerini derinlemesine incelemek hedeflenmiştir. Üçüncü bölüm olan cesaretlendirme aşamasında öğrencilere bilimsel bilginin verilmesi, bilimsel görüşün 
vurgulanması ve bu bilimsel bilginin öğretmen rehberliğinde öğrenciler tarafından anlamlandırılarak içselleştirilmesi sağlanmaktadır. Son bölüm olan uygulama aşamasında ise bilimsel bilgiyi edinen öğrencilerin bu bilgiyi farklı durumlarda analiz edebilmesi ve kullanabilmesi beklenmektedir.

Kontrol grubundaki öğretim sırasında ise 7. sınıf öğretim programına göre ders öğretmenin hazırladığı öğretim planı kullanılmıştır. Öğretmenin hazırladığı ders planına araştırmacı tarafından hazırlanan bu araştırmada kullanılması planlanan etkinlikler eklenmiştir. Kontrol grubundaki öğretime deney grubu ile eş zamanlı olarak başlanmıştır.

\section{Bulgular}

$\mathrm{Bu}$ bölümde enerji dönüşümü kavramı ile ilgili Milli Eğitim Bakanlığı Fen Bilimleri dersi programında yer alan "7.2.4.1. Kinetik ve potansiyel enerji türlerinin birbirine dönüştüğ̈̈nü örneklerle açıklar ve enerjinin korunduğu sonucunu çıkarır." kazanımını ölçmeyi amaçlayan kavramsal anlama testindeki 1. ve 2. sorular ile görüşme verilerinden elde edilen bulgulara yer verilmiştir.

\section{Soruya Ait Bulgular}

Kavramsal anlama testindeki 1. soru öğrencilerin “enerji” ve “enerji dönüşümü” kavramlarıyla ilgili öğrenmelerini değerlendiren bir sorudur. Ağaçtan düşen özdeş iki elmanın yerde bıraktığı izler arasındaki farklılığın nedeni ile ilgili ögrencilerin görüşlerini sorgulayan bu soru araştırmacı tarafından geliştirilmiştir. Deney ve kontrol grubu öğrencilerinin 1. soruya ön test ve son testte verdikleri yanıtların Tablo 2'de ön test ve son test olarak karşılaştırılması yapılmış ve kavramsal değişimleri incelenmiştir.

Tablo 3. Grupların kavramsal anlama testindeki 1. soruya ait yanıtlarının karşıllaştırılması

\begin{tabular}{|c|c|c|c|c|}
\hline \multirow[b]{2}{*}{ YANIT KATEGORILERİ } & \multicolumn{2}{|c|}{ ÖN TEST } & \multicolumn{2}{|c|}{ SON TEST } \\
\hline & $\begin{array}{c}\text { Deney } \\
\text { Grubu } \\
\text { N } \\
(\%)\end{array}$ & $\begin{array}{l}\text { Kontrol } \\
\text { Grubu } \\
\text { N } \\
(\%)\end{array}$ & $\begin{array}{c}\text { Deney } \\
\text { Grubu } \\
\text { N } \\
(\%)\end{array}$ & $\begin{array}{c}\text { Kontrol } \\
\text { Grubu } \\
\mathbf{N} \\
(\%)\end{array}$ \\
\hline $\begin{array}{l}\text { Geçerli Açılama (3) } \\
\text { Elmalardan yüksekte olanın kütle çekim potansiyel enerjisinin daha fazla } \\
\text { olduğundan bahseder. Elmalar yere düşerken potansiyel enerjinin kinetik } \\
\text { enerjiye dönüşeceğini belirtir. }\end{array}$ & - & $x_{2}$ & $\begin{array}{c}4 \\
(26.67)\end{array}$ & $\begin{array}{c}2 \\
(11.11)\end{array}$ \\
\hline $\begin{array}{l}\text { Kısmi Açıklama (2) } \\
\text { Elmaların bıraktığı iz hakkındaki düşüncelerini açıklarken sadece çekim } \\
\text { potansiyel enerjilerinin (ya da yüksekliklerinin) veya kinetik enerjilerinin (ya } \\
\text { da hızlarının) farklı oluşundan bahseder. }\end{array}$ & $\begin{array}{c}10 \\
(66.67)\end{array}$ & $\begin{array}{c}8 \\
(44.44)\end{array}$ & $\begin{array}{c}11 \\
(73.33)\end{array}$ & $\begin{array}{c}11 \\
(61.11)\end{array}$ \\
\hline $\begin{array}{l}\text { Yanlış Kavramla Açıklama (1) } \\
\text { Elmaların bıraktı̆̆ı iz hakkındaki düşüncelerini açıklarken sadece ağırlık, } \\
\text { şekil, hacim, basınç gibi kavramlarla açıklar. }\end{array}$ & $\begin{array}{c}3 \\
(20.00)\end{array}$ & $\begin{array}{c}4 \\
(22.22)\end{array}$ & - & $\begin{array}{c}2 \\
(11.11)\end{array}$ \\
\hline Hiç Açıklamama-Cevap Yok (0) & $\begin{array}{c}2 \\
(13.33)\end{array}$ & $\begin{array}{c}6 \\
(33.33)\end{array}$ & - & $\begin{array}{c}3 \\
(16.67)\end{array}$ \\
\hline
\end{tabular}

Tablo 3'e göre deney ve kontrol grubunda öğretim öncesinde Geçerli Açıklama kategorisinde yer alan yanıt bulunmamaktadır. Her iki grupta da yüksekte olan elmanın kütle çekim potansiyel enerjisinin daha fazla olduğundan bahseden ve elmalar yere düşerken potansiyel enerjilerinin kinetik enerjiye dönüşeceğini belirten öğrenci bulunmamaktadır. Öğretim sonrasında ise bu kategoride yer alan yanıtların oranı deney grubunda daha yüksektir.

Öğretim öncesinde Kısmi Açıklama kategorisine bakıldığında, her iki gruba ait ön test yanıtlarının yoğun olarak bu kategoride yer aldığı görülmektedir. Her iki grupta elmanın düşmesi sırasındaki enerji dönüşümünden bahseden öğrenci bulunmamaktadır. Öğrenciler bu yanıtlarında elmaların izlerinin farklılığının nedeni olarak genellikle elmaların yükseklikleri ve yüksekliklerine bağlı olarak düşme hızlarının farklı olmasından söz etmişlerdir. Buradaki yanıtlar yüzeysel bulunmuştur. Fakat yanıtlarda potansiyel ve kinetik enerjilerin değişkenlerinden bahsedildiği için bu kategoride değerlendirilmiştir. Öğretim sonrasında ise öğrencilerin bu kategorideki yanıtlarında potansiyel ve kinetik enerji kavramlarıyla karşılaşılmıştır. Öğrenciler, elmaların toprakta bıraktıkları izlerin farklılı̆̆ından bahsederken yükseklik farkından kaynaklı potansiyel enerjilerinin farklı olacağını ya da düşme hızlarından kaynaklı kinetik enerjilerinin farklı olacağını vurgulamışlardır. Tablo 3'e göre öğretim sonrasında bu kategoride yer alan yanıtlar her iki grupta eşit sayıda görünse de sadece elmaların yüksekliklerinin farklı olmasından bahseden yüzeysel yanıtlar kontrol grubunda sayıca fazla bulunmuştur.

Bir diğer kategori olan Yanlış Kavramlarla Açıklama kategorisinde yer alan yanıtların oranı iki grupta da oldukça yakındır. Bu öğrenciler ön test yanıtlarında elmaların bıraktığı iz hakkındaki düşüncelerini açıklarken şekil, hacim, basınç gibi enerji ile doğrudan ilişkisi olmayan kavramlarla açıklama yapmışlardır. Öğretim sonrası deney 
grubunda bu kategoriye uygun yanıt veren öğrenci bulunmazken, kontrol grubu öğrencilerinin \%11.11'i, soru metninde özdeş elmalar olduğu vurgulanmasına rağmen, elmaların şekillerinin ve toprağa uyguladıkları basınçların farklılığından dolayı izlerinin farklı olacağından bahsetmişlerdir.

Öğretim öncesinde soruyu yanıtsız bırakan, hiçbir açıklama yapmayan ve Hiç Açıklamama - Cevap Yok kategorisinde yer alan öğrenci oranının kontrol grubunda daha fazla olduğu görülmektedir. Öğretim sonrasında ise deney grubunda bu soruyu yanıtsız bırakan öğrenci bulunmazken, kontrol grubunun \%16.67'si yanıtsız bırakmış ve bu kategoride yer almıştır.

\section{Öğrenci Yanıtlarından Örnekler}

Öğrencilerdeki kavramsal değişimin daha net görülmesi adına DÖ15 kodlu deney grubu öğrencisinin ön test ve son test yanıtları incelendiğinde, 1. soruya ait yanıtı öğretim öncesinde grubun çoğunluğunda olduğu gibi Kısmi Açıklama kategorisindeyken öğretim sonrası Geçerli Açılama kategorisinde yer almıştır. DÖ15, öğretim öncesinde 1. soruya verdiği Şekil 3'teki yanıtında elmanın izlerinin farklı olmasının nedeni olarak sadece yüksekliklerin farklı olmasından bahsetmiş ve yanıtı Kısmi Açıklama kategorisine uygun bulunmuştur.

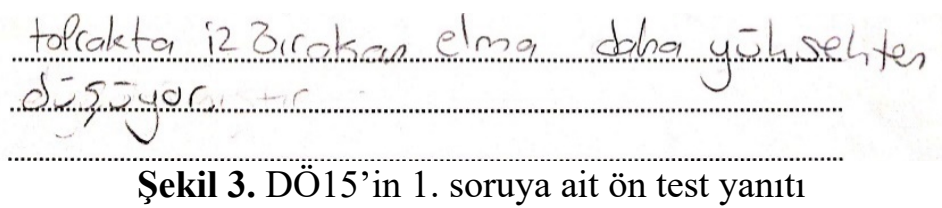

DÖ15' in öğretim öncesinde yaptı̆̆ açıklamalar ise şöyledir:

A : Elmaların bıraktıkları izlerin farklılı̆̆ hakkinda ne düşünüyorsun?

DÖ15 : Yüksekliklerinin farklı olduğu dikkatimi çekti hocam. O yüzden de izlerinin farklı olacağını düşündüm.

A : Nasıl bir farklılık olur izlerde?

DÖ15 : Yüksekte olan topră̆a daha çok gömülebilir. Çünkü o daha çok hızlanabilir. Toprağa olan uzaklığı daha fazla olduğu için.

Ön görüşme sonrasında DÖ15, açıklamasında yüksekte olan elmanın düşerken diğer elmaya göre daha çok hızlanacağı, bu hızından dolayı da toprakta bırakacağı izin daha derin olacağını belirtmiş, potansiyel enerji kavramından ve potansiyel enerji dönüşümünden bahsetmemiştir.

Öğretim sonrasında ise DÖ15, son test yanıtında elmaların potansiyel enerjilerini karşılaştırmış ve potansiyel enerjisi fazla olanın kinetik enerjisinin de fazla olacağını belirtmiştir. DÖ15'in Şekil 4'te görülen son test yanıtı Geçerli Açıklama kategorisinde kaydedilmiştir.

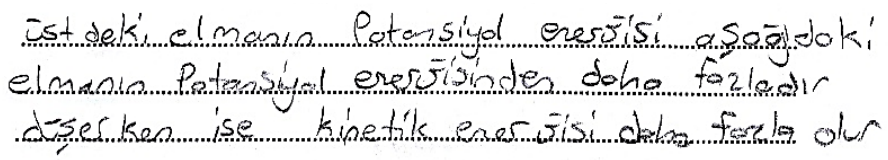

Şekil 4. DÖ15'in 1. soruya ait son test yanıtı

DÖ15, son test yanıtında enerji dönüşümünden doğrudan bahsetmese de düşen elmaların izlerini karşılaştırırken, potansiyel enerjisi fazla olanın kinetik enerjisi de fazla olur düşüncesine sahip olduğu görülmektedir. DÖ15'in enerji dönüşümü ile ilgili açılaması şöyle olmuştur:

A : Burada ăgaçtan düşen elmaların toprakta bıraktıkları izlerin farklı olduğu söyleniyor. Nedeni hakkında ne düşünüyorsun?

DÖ15 : Üstte duran elmanın çekim potansiyel enerjisi aşăğıdakine göre fazladır hocam. Düşerken de bu potansiyel enerji kinetik enerjiye dönüşür. O zaman yüksektekinin kinetik enerjisi fazla olur. Fazla enerjiyle topră̆a düştüğ̈̈ zaman da biraktı̆̆ iz çok olur.

A : Nasıl bir farklllı olur izlerde?

DÖ15 : Üsttekinin enerjisi fazla, daha sert yere düşer. Toprağın içine daha fazla girer.

Son test ve son görüşme cevapları incelendiğinde DÖ15'in yüksekte duran elmanın daha fazla çekim potansiyel enerjisine sahip olduğu için enerji dönüşümü sonucu kinetik enerjisinin de fazla olacağı ve bu enerjiyle de toprakta daha fazla iz bırakacağı bilgisine sahip olduğu görülmektedir. DÖ15, öğretim sonrasında güçlü kavramsal değişim gerçekleştirmiş ve bu kavramla ilgili tam bilimsel bilgiye sahip olmuştur.

Kontrol grubu öğrencilerinden KÖ17 ise ikinci soruya verdiği ve Şekil 5'te görülen ön test yanıtı "Kısmi Açıklama" kategorisinde yer alırken, öğretim sonrası son test yanıtında bir değişiklik olmamış ve yanıtı yine "Kısmi 
Açıklama" kategorisinde yer almıştır. KÖ17, hem öğretim öncesi hem de öğretim sonrası yanıtlarında elmaların yüksekliklerinin farklı olmasından bahsetmiştir.

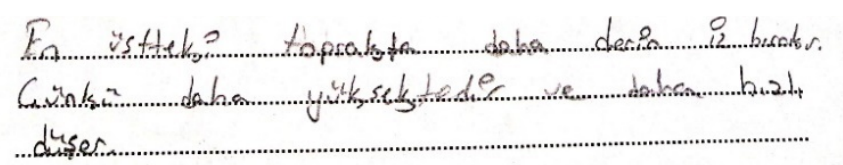

Şekil 5. KÖ17'nin 1. soruya ait ön test yanıt1

KÖ17’nin ön görüşme sırasında 1. soru ile ilgili açıklamaları şu şekilde olmuştur:

A : Düssen elmaların toprakta bıraktıkları izlerin farklılı̆̆ hakkında ne düşünüyorsun?

KÖ17 : Yüksekten düşen elmanin izi derin olur.

A : Neden onun izi derin olur?

KÖ17 : O yukarıda olduğu için hızlanır düşerken. Ondan yere daha hızlı çarpar basınç uygular daha çok topră̆ın içine gömülür.

KÖ17, ön test yanıtında elmanın yüksekte olmasından dolayı düşerken hızlanacağını ve bu yüzden toprakta sert iz bırakacağını belirtmiştir. Öğretim sonrası Şekil 6'daki son test yanıtında yine ön test yanıtına çok benzer bir açılamada bulunmuş, yine elmaların sadece yükseklikleri farklı olduğu için izlerinin farklı olacağından bahsetmiştir.

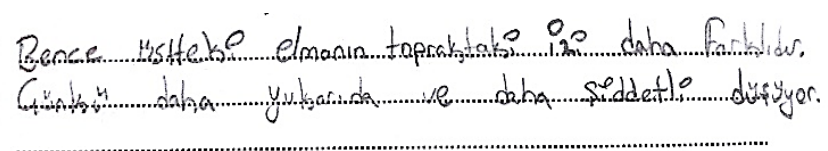

Şekil 6. KÖ17'nin 1. soruya ait son test yanıtı

KÖ17, öğretim sonrasında gerçekleştirilen son görüşme sırasında bu soru için benzer bir yanıt vermiş ve şu şekilde açıklamıştır:

A : Bu soruda düşen elmaların toprakta biraktıklarl izlerin farklılı̆̆ hakkında ne söylersin?

KÖ17 : Bu elmaların biri daha yukarıda. Yüksekten düşen daha hızlı ve daha şiddetli düşer. Sert yere çarpar. İzi fazla olur.

A : Neden izi fazla olur? Hangi etki yani onun izini farklılaştırır?

KÖ17 : Hizı. Hizlı düştügü için zaten toprakta daha çukur oluşur.

A : Peki elmaların enerjileri için ne söylersin? Var mıdır enerjileri?

KÖ17 : Vardir, evet.

A : Hangi tür enerji bunlar?

KÖ17 : Şey olabilir. Yüksekte duran şeylerin enerjisi olan potansiyel enerji.

A : Peki, enerji dönüşümü var midır burada? Bu konuda ne söyleyebilirsin?

KÖ17 : Olabilir. Yüksektekinin potansiyel enerjidir fazladır. Düşerken enerjisi fazla olur.

Son test yanıtında elmaların enerjisi ile fikir belirtmeyen KÖ17, araştırmacının sorusu üzerine elmaların enerjilerinden bahsetmiştir. Özellikle yüksekte duran elmanın sadece potansiyel enerjisinin olacağını belirtmiş, başka tür enerjiden ve enerji dönüşümünden bahsetmemiştir. Öğretim öncesi ve öğretim sonrası yanıtlarında farkl1l1k görülemeyen KÖ17'nin öğretim sonrasında kavramsal değişim gerçekleştiremediği ve bu kavramla ilgili öğrenmesinde eksikliklerin olduğu görülmektedir.

\section{Soruya Ait Bulgular}

2. soru öğrencilerin "enerji” ve "enerji dönüşümü” kavramlarıyla ilgili öğrenmelerini değerlendiren bir sorudur. Soruda verilen saat sarkacının belirtilen 1., 2. ve 3. konumlar arasındaki enerji dönüşümünün varlığı ve hangi türler arasında dönüşüm olduğu sorgulanmaktadır. Tablo 4'te deney ve kontrol grubu öğrencilerinin kavramsal anlama testinde yer alan 2. soruya verdikleri yanıtların ön test ve son test olarak karşılaştırılması yapılmış ve kavramsal değişimleri incelenmiştir. 
Tablo 4. Grupların Kavramsal Anlama Testindeki 2. soruya ait yanıtlarının karşılaştırılması

\begin{tabular}{|c|c|c|c|c|}
\hline \multirow[b]{2}{*}{ YANIT KATEGORİLERİ } & \multicolumn{2}{|c|}{ ÖN TEST } & \multicolumn{2}{|c|}{ SON TEST } \\
\hline & $\begin{array}{c}\text { Deney } \\
\text { Grubu } \\
\mathbf{N} \\
(\%) \\
\end{array}$ & $\begin{array}{c}\text { Kontrol } \\
\text { Grubu } \\
\mathbf{N} \\
(\%) \\
\end{array}$ & $\begin{array}{c}\text { Deney } \\
\text { Grubu } \\
\mathbf{N} \\
(\%) \\
\end{array}$ & $\begin{array}{c}\text { Kontrol } \\
\text { Grubu } \\
\mathbf{N} \\
(\%) \\
\end{array}$ \\
\hline $\begin{array}{l}\text { Geçerli Açıklama (3) } \\
\text { Enerji dönüşümünün var olduğundan bahseder. Doğru konumlar } \\
\text { arasındaki enerji dönüşümünü doğru açılklar. }\end{array}$ & - & - & $9(60.00)$ & $\begin{array}{c}3 \\
(16.67)\end{array}$ \\
\hline $\begin{array}{l}\text { Kısmi Açılama (2) } \\
\text { Enerji dönüşümünün var olduğundan bahseder. Doğru konumlar } \\
\text { arasındaki enerji dönüşümünü kısmen açıklar/açıklamaz. }\end{array}$ & $3(20.00)$ & $\begin{array}{c}4 \\
(22.22)\end{array}$ & $6(40.00)$ & $11(61.11)$ \\
\hline $\begin{array}{l}\text { Yanlış Kavramlarla Açıklama (1) } \\
\text { Enerji dönüşümünün olmadığından bahseder. Konumlar arasında enerji } \\
\text { dönüşümünü açıklamaz. }\end{array}$ & $7(47.67)$ & $\begin{array}{c}6 \\
(33.33)\end{array}$ & - & - \\
\hline Hiç Açıklamama-Cevap Yok (0) & $5(33.33)$ & $\begin{array}{c}8 \\
(44.44)\end{array}$ & - & $4(22.22)$ \\
\hline
\end{tabular}

Tablo 4 incelendiğinde deney ve kontrol grubunda bu soruya ait ön test yanıtları Geçerli Açıklama kategorisinde yer alan öğrenci bulunmadı ̆̆ı, öğretim öncesinde her iki grupta da soruda belirtilen tüm konumlar için enerji dönüşümünü bilimsel olarak açıklayabilen öğrenci bulunmadığı görülmektedir. Bu durum gruplardaki öğrencilerin öğretim öncesinde enerji dönüşümü konusuyla ilgili ön bilgilerinin bilimsel bilgi düzeyinde olmadığını göstermektedir. Öğretim sonrasında deney grubu öğrencilerinin çoğunluğu (\%60.00) Geçerli Açıklama kategorisinde yer alabilecek yanıtlar verirken, kontrol grubunda yanıtı bu kategoride yer alan öğrenci oranı (\%16.67) düşüktür. Öğretim sonrası deney grubu öğrencilerinin büyük çoğunluğu enerji dönüşümünün var olduğundan bahsederek doğru noktalar arasındaki enerji dönüşümünü doğru şekilde açıklamıştır. Deney grubunda geçerli açıklama kategorisinde yanıt verenlerin oranı kontrol grubundan dikkate değer oranda fazladır.

Kısmi Açıklama kategorisine bakıldığında gruplarda yaklaşık olarak eşit oranda öğrencinin ön test yanıtının bu kategoride yer aldığı görülmektedir. Öğretim sonrasında ise gruplarda, bu kategoride yer alan yanıtların oranı kontrol grubunda daha fazladır. Bu kategorideki yanıtlarda enerji dönüşümünün var olduğunu belirtilerek, enerji dönüşümünün hangi türler ve hangi noktalar arasında olduğunu tam açıklamayan öğrenci oranının daha fazla olduğu dikkat çekmektedir.

Öğretim öncesinde gruplarda ön test yanıtları Yanlış Kavramlarla Açıklama kategorisinde yer alan öğrenci oranı birbirine yakın bulunmuştur. Öğrenciler bu kategorideki yanıtlarında enerji dönüşümünün olmadığını belirtmişlerdir. Öğretim sonrasında hem deney hem kontrol grubunda enerji dönüşümü olmadığından bahseden ve son test yanıtı bu kategoride yer alan öğrenci bulunmamaktadır.

Öğretim öncesinde bu soruyu yanıtsız bırakan ve hiçbir açıklama yapmayarak Hiç Açıklamama-Cevap Yok kategorisinde yer alan öğrenci oranı kontrol grubunda daha fazladır. Öğretim sonrasında ise deney grubunda bu soruyu yanıtsız bırakan öğrenci bulunmazken, kontrol grubunun \%22.22'si bu soruyu yanıtsız bırakmıştır.

\section{Öğrenci Yanıtlarından Örnekler}

Deney grubundan DÖ13 kodlu öğrencinin enerji dönüşümünün olmadığını belirttiği ön test yanıtı Yanılıș Kavramlarla Açıklama kategorisinde yer alırken, enerji dönüşümünü tam ve bilimsel olarak açıkladığı son test yanıtı Geçerli Aç̧klama kategorisine uygun bulunmuştur. DÖ13, ön testte Şekil 7'de göründüğü gibi sarkaçta enerji dönüşümü için "yok" yanıtını vermiş ve bu yanıtı Yanlış Kavramlarla Açıklama kategorisinde yer almıştır.

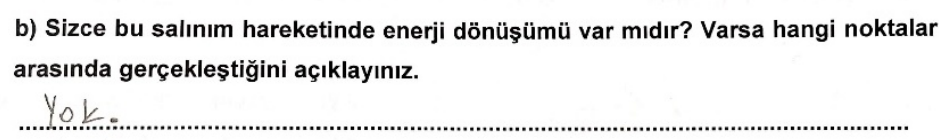

Şekil 7. DÖ13'ün 2. soruya ait ön test yanıtı

Aşağıda DÖ13' ün ön görüşmede bu duruma ilişkin açıklaması sunulmaktadır.

A : Sarkacın şekildeki konumlarda enerjisi hakkında ne söyleyebilirsin?

DÖ13 : I'de enerjisi vardır. 2'de enerjisi yoktur orada duruyor. 3'te enerjisi vardır.

A : Peki var olan konumlardaki enerji türü hakkında ne söyleyebilirsin?

DÖ3 : l'de ve 3'te kinetik enerji var.

A : Kinetik enerjiden bahseder misin biraz? 


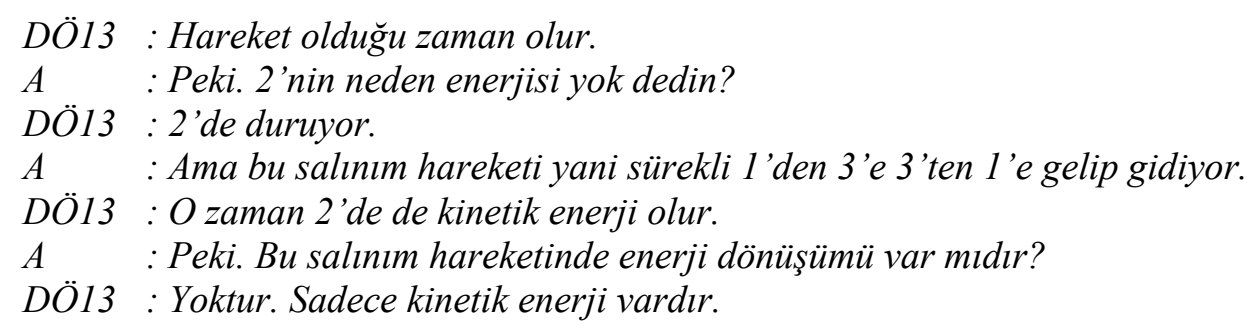

DÖ13, öğretim öncesinde kinetik enerjiden yanlış noktalarda bahsetmektedir. Enerji dönüşümünün olmadığını belirtmiş, sarkacın sadece kinetik enerjisinin olduğunu söylemiştir. Bu durum DÖ13'ün enerji dönüşümü ile ilgili bilimsel bilgisinin olmadığını göstermektedir. Ayrıca DÖ13'ün bu soruda salınım hareketi olduğunu fark edemediği, dolayısıyla da belirtilen konumları nokta olarak değerlendirdiği ve o noktalarda cismin durduğu, sonra yeniden harekete geçtiği şeklinde algıladığı anlaşılmaktadır.

Öğretim sonrasında ise DÖ13, son testteki yanıtında saat sarkacının belirtilen konumlarda enerji türlerini doğru belirlemiş ve enerji dönüşümünün olduğunu belirterek konumlar arasındaki enerji dönüşümünü tam ve bilimsel olarak açıklamıştır. Böylelikle DÖ13'ün Şekil 8'de görülen son test yanıtı Geçerli Açıklama kategorisinde yer almıştır.

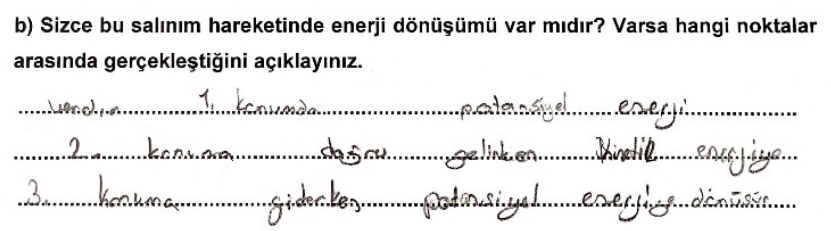

Şekil 8. DÖ13'ün 2. soruya ait son test yanıtı

DÖ13, öğretim sonrasında enerji dönüşümü ile ilgili fikirlerini ise şu şekilde açıklamıştır:

A : Saat sarkacının 1., 2. ve 3. konumlardaki enerjileri hakkinda ne düşünüyorsun?

DÖ13 : l'de potansiyel enerji vardır. 2'de hem potansiyel hem kinetik vardır. Çünkü burada yerden yüksekte ve hareket de var. 3'de sadece potansiyel vardir.

A : Peki enerji dönüşümü desem. Ne söylersin bu sarkacın hareketi sirasında enerji dönüşü mü ile ilgili?

DÖ13 : Yani bence enerji dönüşümü vardır. Söyleyeyim mi?

A : Evet. Söyleyebilirsin tabii.

DÖ13 : Şöyle açıklayayım. l'de potansiyel enerji vardı. 2'ye doğru giderken o kinetik enerji oldu. Sonra 3'e giderken de kinetik yine potansiyel oldu.

A : Peki 2. konumda sadece kinetik enerjisi mi vardır?

DÖ13 : Yok. Aslında orada yerden de yüksekte olduğunu için potansiyel kinetik birlikte. Mekanik yani.

DÖ13 ile yapılan son görüşmede DÖ13'ün öğretim sonrasında enerji türleri ve enerji dönüşümü kavramları ile ilgili bilimsel bilgiyi edindiği, güçlü kavramsal değişim gerçekleştirdiği görülmektedir.

Kontrol grubundaki KÖ8 kodlu öğrenci bu soruya ön testte enerji dönüşümü olmadığını belirterek Yanlış Kavramlarla Açıklama kategorisinde cevap verirken enerji dönüşümünün olduğunu belirttiği ancak tam bilimsel açıklama yapmadığı yanıtı Kısmi Açıklama kategorisinde yer almıştır. Şekil 9'da KÖ8'in ön testteki yanıtı ve ön görüşmede bu duruma ilişkin açıklaması sunulmaktadır.

b) Sizce bu salınım hareketinde enerji dönüşümü var mıdır? Varsa hangi noktalar arasında gerçekleştiğini açıklayınız.

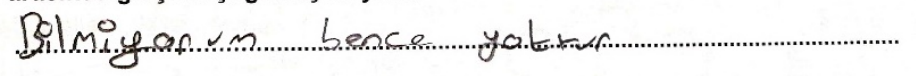

Şekil 9. KÖ8'in 2. soruya ait ön test yanıtı

KÖ8'in öğretim öncesinde bu soru ile ilgili açıklamaları şu şekilde olmuştur:

A : Sarkacın burada belirtilen konumlardaki enerjisi hakkında ne söyleyebilirsin? Bu konumlarda enerjisi var midır?

KÖ8 : Bu şey sallaniyor ya enerjisi vardır.

A : Peki hangi konumlarda enerjisi vardır?

KÖ8 : Hepsinde var. Hareket ediyor. Bunun için enerji lazımdır. Bizim de enerjimiz vardır. 
A : Nasıl bir enerji bu? Biraz daha açıklar misın?

KÖ8 : Evet. Yani dediğim yediğimiz şeylerden gelen bir enerji. Yediklerimiz sindirilince bize enerji olarak geri dönüyor. Bunun sayesinde hareket ediyoruz. İște spor yapıyoruz işlerimizi yapıyoruz. Mesela çikolata gibi falan yiyecekler çok enerji veriyor.

A : Peki. Enerji dönüşümü için ne söyleyebilirsin? Burada enerji dönüşümünden bahsedebilir miyiz?

KÖ8 : Bunu bilmiyorum açıkçası. Sınavda yok demiştim de bilmiyorum aslında hocam. Enerji dönüşümü deyince yediklerimizin enerji olarak geri dönmesi geldi ama buradakiyle bir şey kuramadim bir alaka yani. Yani bilmiyorum.

KÖ8'in ön görüşmedeki açıklamalarından bu araştırmanın kavramlarından olan mekanik enerji ile vücudumuzda meydana gelen kimyasal enerjiyi karıştırdığı görülmektedir. Ayrıca KÖ8'in enerji dönüşümü kavramına ait bilimsel bilgisi bulunmadığı ve enerji dönüşümü olmadığına dair yanıtını sezgisel olarak verdiği anlaşılmaktadır.

Kontrol grubu öğrencisi KÖ8 öğretim sonrası yanıtında enerji dönüşümünün var olduğunu ve sadece 1. ve 3 . konumda olduğunu belirtmiştir. Şekil 10'da son test yanıtı görülen KÖ8'in bu düşüncesine dair son görüşme yanıtı aşağıdaki gibi olmuştur.

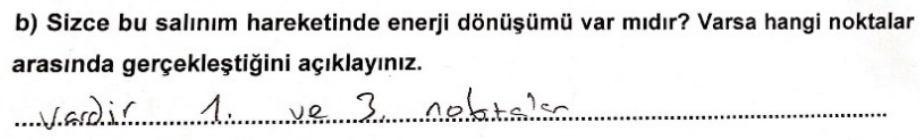

Şekil 10. KÖ8' in 2. soruya ait son test yanıtı

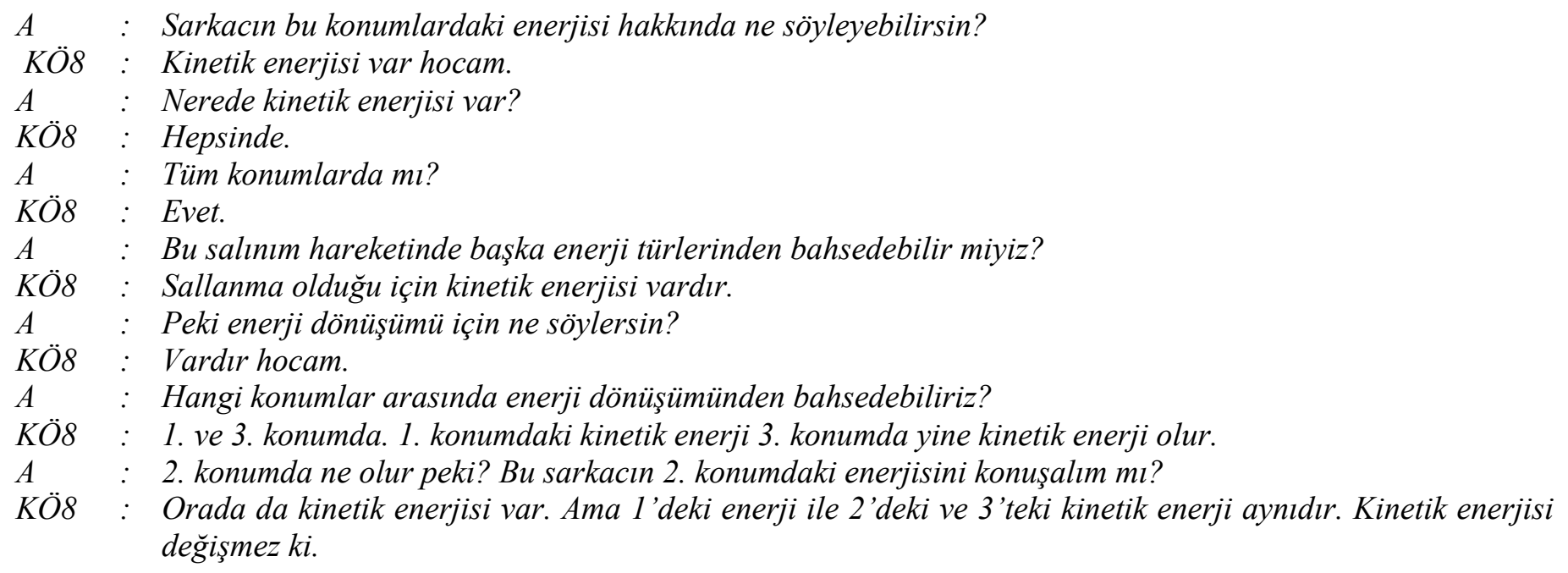

KÖ8'in öğretim sonrasında yaptığı açıklamalarında konumlar arasında değil, konumlarda enerji dönüşümünün olacağını belirtmesi dikkat çekmektedir. KÖ8, salınım hareketinden dolayı sarkacın sadece kinetik enerjiye sahip olacağını belirtmiş ve potansiyel enerjiden hiç bahsetmemiştir. KÖ8'in enerji dönüşümü ile ilgili açıklamasında tüm konumlarda sarkacın kinetik enerjisinin olduğunu ve bu kinetik enerjinin hareket boyunca değişmeyeceğini belirtmesi enerji dönüşümü ve enerji korunumu kavramlarını birbiri yerine kullandığını göstermektedir.

\section{Sonuç, Tartışma ve Öneriler}

Kavramsal Anlama Testinde öğrencilerin enerji dönüşümü kavramına ait öğrenmelerini değerlendirmek amacı ile hazırlanan 1. ve 2. sorular aynı zamanda öğrencilerin enerji korunumu hakkında bilgilerini ve kavramsal anlamalarını da ölçmektedir. Ön test bulgularından öğretim öncesinde hem deney hem de kontrol grubu öğrencilerinin iki soruya da verdikleri yanıtlarda enerji korunumuna ilişkin tam bilimsel bilgiye sahip olmadıkları anlaşılmaktadır. 1. soruya ait ön test yanıtlarında öğrenciler genellikle yüksekte olan elmanın düşerken hızlanacağından izlerin farklılık göstereceği yönünde görüş bildirmişlerdir. Deney grubunda $\% 66.77$ ve kontrol grubunda $\% 44.44$ oranında öğrenci yanıtı, potansiyel enerjinin yükseklik değişkenini içerdiği için Kısmi Açıklama kategorisinde yer almıştır. Fakat bu yanıtlarda enerji dönüşümünden bahsedilmemiştir. Bir basit sarkacın belirlenen noktalar arasındaki enerji dönüşümünün açılanması istenen 2. soruda ise her iki grupta da isteneni açılayabilen ve ön test yanıtı Geçerli Açılama kategorisinde yer alan öğrenci bulunmamıştır. Öğretim öncesi deney grubunda \%46.67, kontrol grubunda ise \%33.33 
gibi yüksek oranda öğrencilerin enerji dönüşümü ile ilgili tereddüt yaşadığı ve Yanlış Kavramlarla Açılama kategorisine uygun yanıt verdiği görülmektedir. $\mathrm{Bu}$ soruda da yukarıda bahsedildiği gibi enerjinin "hareket" kavramıyla doğrudan ilişkilendirildiği ve sarkacın özellikle durduğunun varsayıldığı noktada enerjisinin de olmadığının düşünüldüğü sonucuna varılmıştır. Bu duruma DÖ3'ün "Hareket etmiyorsa enerjisi yoktur." ve KÖ4'ün "Sadece hareket ettiği konumlarda enerjisi vardır." açıklamaları örnek verilebilir. Elde edilen sonuçlar Madanoğlu (2015), Ünal - Çoban, Aktamış ve Ergin (2007)'in öğrencilerin enerjiyi hareket kavramıyla ilişkilendirdiğini vurgulayan çalışmalarındaki bulgularla uyumlu bulunmuştur.

Kruger (1990), ilköğretim düzeyindeki öğrencilerin enerji konusundaki anlama düzeylerini araştırdığ1 çalışmasında "duran nesnelerin enerjisinin bulunmadığı" yanılgısı ile karşılaşmıştır. Bu türden yanılgının oluşmasında yine öğrencilerin sosyal yaşamlarındaki gözlemlerinin ve günlük deneyimlerinin etkisi olduğu düşünülmektedir (Zhang, Chen, \& Ennis, 2019). Öğrenciler bu soruda salınım hareketi yapan saat sarkacının enerjisinin bulunmadığ 1 konumlar olduğunu düşündükleri için enerji dönüşümünün de olmadığını belirtmişlerdir. Aynı durum 1. soruda ağaçta asılı şekilde duran elmaların enerjisi ile ilgili soruya verilen yanıtlarda da görülmüştür. Öğrenciler ağaçta duran elmaların enerjisi olabileceğinden bahsetmemişler, elmalar düşmeye başladıkları andan itibaren elmaların hızlarının etkisiyle toprakta farklı izler bırakacaklarını belirtmişlerdir. Öğrenciler ağaçta duran elmaların sahip oldukları potansiyel enerji ve düşme sırasında meydana gelen enerji dönüşümü ile ilgili bilimsel bilgiye sahip olmamalarından kaynaklı, düşmeleri esnasında potansiyel enerjinin kinetik enerjiye dönüşeceği yönünde görüş belirtememişlerdir.

Yağbasan ve Gülçiçek (2003), çalışmalarında 10. sınıf öğrencilerinin basit sarkacın toplam enerji değerinin yani mekanik enerjisinin kinetik ve potansiyel enerji değerlerinin toplamı olduğu bilgisine sahip olmadığını ve toplam enerji değerinin korunduğunu ifade edemediklerini belirtmiştir. Öğrencilerin bir kısmının basit sarkaç hareketi yapan bir kütlenin toplam enerjisinin değişmeyeceğini düşünmedikleri de bu araştırmanın sonuçlarındandır. Bahsi geçen araştırmanın sonucuna benzer şekilde bu araştırmada 7. sınıf düzeyinde olan öğrencilerin 2. soruda bir saat sarkacının salınım hareketi esnasında enerjisinin dönüşeceğinden ve mekanik enerjisinin korunacağından bahsetmedikleri görülmüştür. Her iki gruptaki öğrencilerin öğretim öncesi yanıtları çoğunlukla Yanlış Kavramlarla Açıklama kategorisinde bulunmuştur. Kontrol grubu öğrencilerinden KÖ4'ün "Enerji dönüşmez. Enerji, enerji olarak kalır." ifadesi, öğretim öncesinde enerji hakkındaki bilgisinin yetersiz olduğunu göstermektedir.

Öğretim sonrası grupların son test yanıtlarına bakıldığında her iki grupta da enerji dönüşümüne ilişkin bilimsel bilgiyi edinen, bu bilgisini farklı durumlarda kullanabilen öğrenciler olduğu görülmektedir. 1. soru için deney grubunda kontrol grubuna göre daha fazla oranda öğrenci elmanın düşmesi sırasında meydana gelen enerji dönüşümünü açıklamıştır. Özellikle 2. soruda deney grubunda yer alan basit sarkacın salınımı sırasında meydana gelen enerji dönüşümünü Geçerli Açıklama kategorisine uygun şekilde bilimsel olarak açılayabilen öğrenci oranı \%66.67'lere yükselmiştir. Kontrol grubunda ise bu oran yaklaşı \%30.00 düzeyinde kalmış ve öğrenciler, enerjiyi sadece hareket ile ilişkilendirme yanılgısına devam etmişlerdir. Bu gruptaki öğrenciler saat sarkacının her konumda hareketinden dolayı kinetik enerjiye sahip olduğunu belirtmişler ve enerji dönüşümünü açıklamamışlardır. Anlam oluşturma yaklaşımına dayalı öğretimin gerçekleştirildiği deney grubunda bu türden bir yanılg1 ile karşılaşılmazken, kontrol grubunda uygulanan ve Milli Eğitim Bakanlığı tarafından önerilen programın bu yanılgıyı gidermede etkisinin düşük olduğu söylenebilir.

Çalışma bulgularına göre öğrenci-öğrenci ve öğrenci-öğretmen arasındaki sosyal etkileşimler, öğrencilerin sosyal öğrenmeleri nedeniyle oluşan ön bilgilerinde kavramsal değişim meydana gelmesini sağlayarak bu bilgilerin bilimsel bilgilere dönüşmesinde etkili olmuştur. Öğretim sonrası deney grubuna ait son test yanıtlarının büyük bir çoğunluğunda enerji dönüşümü kavramına ilişkin bilimsel bilginin yer aldığı görülmüsşür. Buna göre anlam oluşturma yaklaşımı ile tasarlanan öğretimin öğrencilerin enerji dönüşümü kavramına ilişkin kavramsal anlamalarını geliştirme ve başarılarını arttırma yönünden etkisi olduğu düşünülmektedir.

Çalışmada anlam oluşturma yaklaşımının "öğrenme sosyal bir süreçtir” algısına uygun olarak sınıf içerisinde grup içi ve gruplar arası tartışma ortamları oluşturulmuş, öğrencilere fikirlerini sunma ve bu fikirlerini diğer arkadaşlarıyla paylaşma imkânı verilmiştir. Bu sayede araştırma sonunda tartışma ortamlarının öğrencilerin fikirlerini etkilediği, bilgiyi anlamlandırma ve bilişsel çatışma yaşayarak kavramsal değişim sürecini başlatma noktasında olumlu etkisinin olduğu görülmüştür. Ecevit ve Şimşek (2017), Fen Bilimleri dersi öğretmenlerinin kavram yanılgılarıyla ilgili görüşlerini değerlendirdikleri çalışmalarında öğretmenlerin derslerinde zaman yetersizliğinden dolayı çok fazla tartışma ortamı oluşturamadıklarını, dolayısıyla da öğrencilerin kavram yanılgılarını tespit etmede yetersiz kaldıklarını belirtmişlerdir. Bu çalışmada kullanılan öğretim tasarımıyla her dersin başlangıç aşamasında öğrencilerin ön bilgileri ile kavram yanılgılarının tespiti ve öğrenci fikirlerinin paylaşımı için süre ve imkân yaratılmıştır. Yukarıda açıklandığı gibi bu araştırmada kullanılan türden öğretim planları, her bir fen dersinin öğretiminin sistematik hale getirilmesine ve bu derslerde grup çalışmalarının yapılmasına imkân yaratarak öğretim sürecinde tüm öğrencilerin gruplar aracılığıyla fikirlerini açıklamasını sağlayacaktır. Böyle bir süreçte öğretmen fikirlerin sunulmasını sağlamada ve fikirleri seçme konusunda hassas davranmalı, bilimsel bilgiye uzak olan fikirlerin öğrenciler tarafından mantıklı bulunarak bu fikirden etkilenilmesinin önüne geçecek etkinlikler ile bilişsel ve duyuşsal kontrolü sağlamalıdır. 
$\mathrm{Bu}$ araştırma kapsamında, öğretimin üretken öğrenme modeli basamaklarına uygun olarak tasarlanmış anlam oluşturma yaklaşımı kullanılarak hazırlanan öğretim planı ile enerji dönüşümü kavramının öğretimi yapılmıştır. Hazırlanan bu öğretim programında öğrencilerin enerji kavramına ilişkin bilimsel bilgiyi kazanırken öğretim süresinin verimli kullanıldığı gözlemlenmiştir. Bundan sonraki çalışmalarda fen bilimleri dersine ait enerji dönüşümü kavramından farklı kavramların öğretimi sırasında bu araştırmada benimsenen öğretimin üretken öğrenme modeline anlam oluşturma yaklaşımı temelli öğretim tasarlanarak böyle bir öğretim tasarımının sonuçları irdelenebilir. Bu çalışmadaki benzer öğretim yaklaşımı ve modeli kullanılarak hazırlanan öğretim planları farklı sınıf düzeylerinde farklı konularda da uygulanabilir. Böyle uygulamaların bu araştırmanın dış geçerliğine de katkısının olacağı düşünülmektedir.

\section{Araştırmacıların Katkı Oranı}

Bu çalışma birinci yazarın ikinci yazarın danışmanlığında gerçekleştirdiği doktora tez çalışmasının bir bölümüdür

\section{Destek ve Teşekkür}

Bu çalışma Balıkesir Üniversitesi Bilimsel Araştırma Projeleri (BAP) kapsamında 2017/069 proje numarası ile desteklenmiştir.

\section{Çıkar Çatışması}

Yazarlar çalışmada herhangi bir çıkar çatışmasının bulunmadığını beyan etmişlerdir. 


\section{Kaynakça / References}

Abraham, M. R., Grzybowski, E. B., Renner, J. W., \& Marek, E. A. (1992). Understandings and misunderstandings of eighth graders of five chemistry concepts found in textbooks. Journal of Research in Science Teaching, 29(2), 105-120.

Alexander, P. A., \& Dochy, F. J. (1995). Conceptions of knowledge and beliefs: A comparison across varying cultural and educational communities. American Educational Research Journal, 32(2), 413-442.

Alyar, M., \& Doymuş, K. (2015). Maddenin tanecikli yapısının anlaşılması üzerine işbirlikli öğrenme yöntemlerinin etkisi. Ahi Evran Üniversitesi Kırşehir Eğitim Fakültesi Dergisi, 16(2), 371-389.

Aytaçlı, B. (2012). Durum çalışmasına ayrıntılı bir bakış. Adnan Menderes Üniversitesi Ĕgitim Fakültesi Ĕ̆itim Bilimleri Dergisi, $3(1), 1-9$.

Baykal, B. (2014). Fen ve Teknoloji dersi öğretmenlerinin sınıf içi iletişim ve etkileşimlerinin analizi: Diyalojik ve otoriter tartışmalar (Yayınlanmamış yüksek lisans tezi). Niğde Üniversitesi, Niğde.

Bıyıklı, C., \& Yağcı, E. (2015). 5E öğrenme modeline göre düzenlenmiş eğitim durumlarının akademik başarı ve tutuma etkisi. Abant İzzet Baysal Üniversitesi Ĕ̈itim Fakültesi Dergisi, 15(1), 302-325.

Bostan Sarığlan, A. (2013). Tork, açısal momentum ve Kepler yasalarına ilişkin yapılan öğretimin ortaöğretim onbirinci sınıf ögrencilerinin anlam oluşturma süreçlerine etkisi (Yayınlanmamış doktora tezi). Balıkesir Üniversitesi, Balıkesir.

Cosgrove, M., \& Osborne, R. (1985). Lesson frameworks for changing children's ideas. In R. Osborne and P. Freyberg (Eds.). Learning in science: The implications of children's science (pp.101-112), Hong Kong: Heinemann Education.

Çinici, A. (2011). Lise öğrencilerinin hayvanların sınıflandırılması ile ilgili alternatif kavramları: Omurgalı hayvanlar. Türk Fen Ë̆itimi Dergisi, 8(4), 171-187.

Dale Tunnicliffe, S., \& Gkouskou, E. (2020). Science in action in spontaneous preschool play-an essential foundation for future understanding. Early Child Development and Care, 190(1), 54-63.

Derry, S. J. (1999). A fish called peer learning: Searching for common themes. In A. M. O'Donnell and A. King (Eds.), Cognitive Perspectives on Peer Learning (pp. 197-211), New Jersey: Lawrence Erlbaum Associates.

Driver, R., Leach, J., Scott, P., \& Wood-Robinson, C. (1994). Young people's understanding of science concepts: Implications of cross-age studies for curriculum planning. Studies in Science Education, 24, 75-100.

Driver, R., Newton, P., \& Osborne, J. (2000). Establishing the norms of scientific argumentation in classrooms. Science Education, 84, 287-312.

Ecevit, T., \& Şimşek, P. Ö. (2017). Öğretmenlerin fen kavram öğretimleri, kavram yanılgılarını saptama ve giderme çalışmalarının değerlendirilmesi. Elementary Education Online, 16(1), 129-150.

Eun, B. (2017). Drama as a Powerful Tool for Literacy Instruction: A Sociocultural Approach. Educational Research Applications, ERCA 120. doi:10.29011/2575-7032/100020

Feyzioğlu Yıldız, E., \& Ergin, Ö. (2012). 5E öğrenme modelinin kullanıldığı öğretimin yedinci sınıf öğrencilerinin üst bilişlerine etkisi. Türk Fen Eğitimi Dergisi, 9(3), 55-77.

Furberg, A., \& Arnseth, H. C. (2009). Reconsidering conceptual change from a socio-cultural perspective: analyzing students' meaning making in genetics in collaborative learning activities. Cultural Studies of Science Education, 4(1), $157-191$.

Gilbert, J. K., Bulte, A. M., \& Pilot, A. (2011). Concept development and transfer in context-based science education. International Journal of Science Education, 33(6), 817-837.

İpek Akbulut, H., Şahin, Ç., \& Çepni, S. (2013). İş ve enerji konusu ile ilgili kavramsal değişimin incelenmesi: İkili yerleşik öğrenme modeli örneği. Mehmet Akif Ersoy Üniversitesi Eğitim Fakültesi Dergisi, 13(25), 24-268.

Kaya, O. N., \& Kılıç, Z. (2010). Fen sınıflarında meydana gelen diyaloglar ve öğrenme üzerine etkileri. Kastamonu Ĕ̆itim Dergisi, 18(1), 115-130. 
Kıncal, R.Y., Ergül, R., \& Timur, S. (2007). Fen bilgisi öğretiminde işbirlikli öğrenme yönteminin öğrenci başarısına etkisi. Hacettepe Üniversitesi Ĕ̆itim Fakültesi Dergisi, 32, 156-163.

Kıryak, Z., \& Çepni, S. (2015). Fen bilimleri ders kitabında kullanılan fizik dilinin 7. sınıf öğrencileri tarafından algılanma biçimleri. Milli Eğitim Dergisi, 45(207), 145-168.

Kural, M., \& Kocakülah, M. S. (2014). Fikirler arası çatışmaya dayalı öğretimin öğrencilerin ince zarda girişim konusundaki kavramsal anlamalarına etkisi. Amasya Üniversitesi Ĕ̆itim Fakültesi Dergisi, 3(1), 50-97.

Kruger, C. (1990). Some primary teachers' ideas about energy. Physics Education, 25(2), 86-91.

Leach, J., \& Scott, P. (2003). Individual and sociocultural views of learning in science education. Science \& Education, 12(1), 91113.

Madanoğlu, N. (2015). 9. sınıf öğrencilerinin iş ve enerji konusundaki kavramsal anlamalarının incelenmesi (Yayınlamamış yüksek lisans tezi). Balıkesir Üniversitesi, Balıkesir.

Mahn, H. (2012). Vygotsky's analysis of children's meaning making processes. International Journal of Educational Psychology, $1(2), 100-126$.

Moll, L. C., \& Whitmore, K. (1993). Vygotsky in educational practice. In E. Forman, N. Minick and C. A. Stone (Eds.), Contexts for learning: Sociocultural dynamics in children's development (pp. 19-42), New York: Oxford.

Mortimer, E., \& Scott, P. (2003). Meaning making in secondary science classrooms. Berkshire: McGraw-Hill Education.

Murphy, C., Scantlebury, K., \& Milne, C. (2015). Using Vygotsky's zone of proximal development to propose and test an explanatory model for conceptualising coteaching in pre-service science teacher education. Asia-Pacific Journal of Teacher Education, 43(4), 281-295.

Oldfather, P., West, J., White, J., \& Wilmarth, J. (1999). Learning Through Children's Eyes: Social Constructivism and the Desire to Learn. Washington: American Psychological Association.

Öztürk Ova, N. (2011). Güzel sanatlar lisesi öğrencileri ile fen lisesi öğrencilerinin eleştirel düşünme ve üstbiliş eğilimlerinin karşılaştırılması (Yüksek lisans tezi). Yükseköğretim Kurulu Ulusal Tez Merkezi veri tabanından erişildi (Tez No. 292908).

Phaikhumnam, W., \& Yuenyong, C. (2018). Improving the primary school science learning unit about force and motion through lesson study. AIP Conference Proceedings, January, 2018. New York: AIP Publishing.

Phillips, D. C. (Ed.). (2000). Constructivism in Education. Chicago: National Society for the Study of Education.

Rakkapao, S., Pengpan, T., Srikeaw, S., \& Prasitpong, S. (2013). Evaluation of POE and instructor-led problem-solving approaches integrated into force and motion lecture classes using a model analysis technique. European Journal of Physics, $35(1), 1-10$.

Rieber R.W. (Eds.). (1998). Development of thinking and formation of concepts in the adolescent. The Collected Works of L. S. Vygotsky. Boston: Springer.

Schunk, D. H. (2011). Öğrenme teorileri-eğitimsel bir bakışla (2. Baskı). (Çev. Ed. M. Y. Demir), Ankara: Nobel Yayıncılık.

Scott, P. H., Mortimer, E. F., \& Aguiar, O. G. (2006). The tension between authoritative and dialogic discourse: A fundamental characteristic of meaning making interactions in high school science lessons. Science Education, 90(4), 605-631.

Selvi, K. (2012). Creation and construction of knowledge in learning-teaching process. In A.T. Tymieniecka (Eds.). Phenomenology and the Human Positioning in the Cosmos (pp. 167-179). Dordrecht: Springer.

Siyepu, S. (2013). The zone of proximal development in the learning of mathematics. South African Journal of Education, 33(2), $1-13$.

Şahin, Ç., \& Çepni, S. (2012). 5E öğretim modeline dayalı öğretimin öğrencilerin gaz basıncı ile ilgili kavramsal anlamalarına etkisi. Necatibey Eğitim Fakültesi Elektronik Fen ve Matematik Eğitimi Dergisi, 6(1), 220-264. 
Şencan, D. (2013). Günlük yaşam problemlerinin 7. sınıf öğrencilerinde bilimsel süreç becerileri, akademik başarı ve bilim okuryazarlı̆̆ı üzerine etkisi: Kuvvet ve hareket (Yayınlanmamış yüksek lisans tezi). Marmara Üniversitesi, İstanbul.

Terwel, J. (1999). Constructivism and its implications for curriculum theory and practice. Journal of Curriculum Studies, 31(2), 195-199.

Ünal Çoban, G., Aktamış, H., \& Ergin, Ö. (2007). The views of 8 th grade students about energy. Gazi Üniversitesi Kastamonu Ĕ̈itim Dergisi, 15(1), 175-184.

Üstünkaya, I., \& Savran Gencer, A. (2012). İlköğretim 6. sınıf seviyesinde bilimsel tartışma (argumentation) odaklı etkinliklerle dolaşım sistemi konusunun öğretiminin akademik başarıya etkisi. X. Ulusal Fen ve Matematik Eğitimi Kongresi Bildiri Kitabı. Ankara: Pegem Akademi.

Wertsch, J. V. (1991). Voices of the mind-a sociocultural approach to mediated action. Hempstead: Harvester Wheatsheaf.

Yağbasan, R., \& Gülçiçek,. Ç. (2003). Fen öğretiminde kavram yanılgılarının karakteristiklerinin tanımlanması. Pamukkale Üniversitesi Eğitim Fakültesi Dergisi, 13, 102-120.

Yeh, S. C., Huang, J. Y., \& Yu, H. C. (2017). Analysis of energy literacy and misconceptions of junior high students in Taiwan. Sustainability, 9(3), 423.

Yıldırım, A. ve Şimşek, H. (2011). Sosyal bilimlerde nitel araştırma yöntemleri (8. Baskı). Ankara: Seçkin Yayıncılık.

Zhang, T., Chen, A., \& Ennis, C. (2019). Elementary school students' naïve conceptions and misconceptions about energy in physical education context. Sport, Education and Society, 24(1), 25-37. 